\title{
Investment Risk: Empirical Evidence from Indonesia Stock Exchange
}

\author{
Herma Wiharno ${ }^{1}$, Teti Rahmawati ${ }^{2}$, Lia Dwi Martika ${ }^{3}$, Arief Nurhandika ${ }^{4}$, Rosi Utari \\ Dewi $^{5}$ \\ ${ }^{12345}$ Fakultas Ekonomi, Universitas Kuningan, Indonesia \\ \{herma.wiharno@uniku.ac.id ${ }^{1}$, teti.rahmawati@uniku.ac.id², lia.dwimartika@uniku.ac.id ${ }^{3}$ \\ arief.nurhandika@uniku.ac.id ${ }^{4}$, rosi.utari.dewi@uniku.ac.id $\left.{ }^{5}\right\}$
}

\begin{abstract}
This study aims at obtaining empirical evidence that can explain the influence of Asset Growth, Leverage-measured by Debt to Equity Ratio (DER), Profitability of Return on Asset (ROA), and Company Size, either simultaneously or partially on Investment Risk in the Coal Mining Sub-Sector Company Listed on the Indonesia Stock Exchange (IDX) for the 2014-2018 Period. This study used quantitative data in financial reports registered in Indonesia Stock Exchange (IDX). The population in this study are coal mining sub-sector companies listed on the IDX. While the sample in this study was determined using the quota sampling method to obtain a sample of 19 companies. The type of data used in this study was secondary data obtained from www.idx.co.id. The analysis technique used in this research was panel data regression analysis using the Eviews program version 9.0, hypothesis testing used t-statistic and f-statistic. The classical assumption test shows that the available data met the requirements to use the panel data regression equation model. The results show that the Asset Growth, Leverage, Profitability, and Company Size have simultaneous and significant effect on Investment Risk. Furthermore, the partial analysis shows that Asset Growth has significant and negative effect on Investment Risk, Leverage has significant and positive effect on Investment Risk, Profitability has significant and negative effect on Investment Risk, and Company Size has significant and negative effect on Investment Risk.
\end{abstract}

Keywords: Asset Growth; Leverage; Profitability; Company Size; Investment Risk

\section{Introduction}

In recent years, investment in the coal mining sector has continued to increase. There are interesting things, direct investment from domestic investment (PMDN) is actually higher than foreign investment (PMA). This shows that local coal companies are able to host in their own country. On the other hand, there is a tendency for foreign investors to choose to reduce their investment in this sector due to regulatory uncertainty from the government. There are concerns that government policies that often change and relatively high taxes will hamper the development of the coal mining sector in Indonesia. An investor can maximize the rate of return obtained and minimize the potential risk that will occur. To calculate the risk in an investment, investors can use the standard deviation method. Where risk is measured based on probability and risk based on historical data (Jogiyanto, 2010).

Some of the factors that cause an increase or decrease in investment risk include asset growth, profitability leverage and company size. Asset growth are assets used for the company's operational activities. The bigger the assets, it is expected that the greater the 
operational results generated by the company. An increase in assets followed operating results will increase the trust from outsiders to the company. Asset growth before the crisis has an effect on stock beta asset growth. In the period during the crisis, the results of multiple regression analysis show that six factors have a positive effect on stock beta (Rina Dwi Arti, 2019). Leverage is a ratio that describes the relationship between corporate debt to capital or assets. An investor must look at the leverage ratio of a company; a good corporate leverage ratio is if total assets are greater than total debt. The better the level of leverage will have an effect on changes to the stock beta (Ainur Rofiq Kurniawan, 2018). Operating leverage and financial leverage have a significant effect on systematic risk (Aprida Rinaldo, 2018).

Profitability is the ability of a company to generate profits for a certain period at the level of sales, assets and share capital (Jeremy Liam Wijaya, 2018). Profitability ratio consist of several ratios, one of which is return on assets. The greater the return on assets ratio, the better the condition of the company, so that it will increase investor trust in investment (Lukman, 2009). The better the level of company profitability has an effect on the increase in the potential risk of the company (Desrinda Imelda (2014; Muhamad Ito Andhika, 2014). Company size is a comparison of the company's business size. According to Sujoko (2007), a large company size shows that the company has developed so that investors will respond positively and company value will increase. Small companies are preferring risk over large companies (Desi, 2014).

Table 1. Expected Return, Investment Risk and Covariance Coal Mining Company

\begin{tabular}{|c|c|c|c|c|c|c|c|c|}
\hline \multirow{2}{*}{$\frac{\text { No }}{1 .}$} & \multirow{2}{*}{$\begin{array}{l}\begin{array}{l}\text { Issuer } \\
\text { Code }\end{array} \\
\text { ADRO }\end{array}$} & \multicolumn{3}{|c|}{$\begin{array}{c}\text { Average } 2014-2018 \\
E(R)\end{array}$} & \multirow{2}{*}{$\begin{array}{c}\text { No } \\
12 .\end{array}$} & \multirow{2}{*}{$\begin{array}{c}\begin{array}{c}\text { Issuer } \\
\text { Code }\end{array} \\
\text { ITMG }\end{array}$} & \multicolumn{2}{|c|}{$\begin{array}{c}\text { Average 2014 -2018 } \\
\mathrm{E}(\mathrm{R}) \\
\end{array}$} \\
\hline & & 0,0076 & 0,0956 & $-152,857$ & & & 0,0052 & 0,1404 \\
\hline 2. & ARII & 0,0118 & 0,1206 & $-10,863$ & 13. & KKGI & $-0,0058$ & 0,1508 \\
\hline 3. & ATPK & $-0,005$ & 0,0224 & $-2,528$ & 14. & MYOH & 0,0162 & 0,083 \\
\hline 4. & BSSR & 0,0084 & 0,0996 & 813 & 15. & PKPK & 0,0246 & 0,2004 \\
\hline 5. & BUMI & 0,0128 & 0,2698 & 667 & 16. & PTBA & 0,006 & 0,1454 \\
\hline 6. & BYAN & 0,0204 & 0,1036 & 596 & 17. & PTRO & 0,0184 & 0,1408 \\
\hline 7. & DEWA & 0,0062 & 0,0832 & 16,592 & 18. & SMMT & 0,0172 & 0,3252 \\
\hline 8. & DOID & 0,0578 & 0,2578 & $-6,702$ & 19. & TOBA & 0,018 & 0,0864 \\
\hline 9. & GEMS & 0,0072 & 0,081 & $-1,488$ & 20. & MBAP & 0,02 & 0,0976 \\
\hline 10. & GTBO & 0,0008 & 0,2298 & 19,313 & 21 & FIRE & 0,0076 & 0,0956 \\
\hline 11. & HRUM & 0,0034 & 0,1598 & 15,573 & & ta-rata & 0,011962 & 0,137771 \\
\hline
\end{tabular}

Investment is a commitment of assets or other resources that are carried out at this time with the hope of obtaining returns in the future (Tandelilin, 2010: 13). There are two chance faced by investors in investment, that is result of the largest expected return with certain risk or certain level of return with the smallest risk (Husnan, 2001: 175). In investment, there are two factors that must be considered together, that is the expected return and risk. That getting smaller the $\mathrm{CV}$ value then better the assets, getting smaller the CV shows that getting smaller the risk and getting greater the expected return (Hartono, 2017). The coefficient of variation is useful in deciding the choice of investments between those with high returns and those with low risk. 
The coefficient of variation shows the amount of risk for each return. In other words, getting smaller the $\mathrm{CV}$ value shows getting smaller the investment risk and getting greater the expected return. Based on the results of data processing in table 1, it can be seen that from 21 coal mining sub-sector companies listed on the IDX during the 2014-2018 period, only 6 companies had low CV values, while 15 other companies had high CV values. So it can be said that investment in coal mining companies is very risky. This encourages researchers to conduct research on investment risks in the mining sector. Based on the formulation of the problem above, the purpose of this research is to obtain empirical facts that can explain: The effect of asset growth, leverage, profitability and company size on investment risk.

\section{Method}

Asset growth is the change in the company's annual growth rate of total assets. The higher the company's asset growth indicates that the company has the opportunity to carry out business development. With the existence of business development, it will certainly encourage an increase in profits. Companies with high profits will encourage investors to invest and increase share prices, so can minimizing risk. The effect of asset growth on investment risk in this study is based on the results of research by Elly Indrianto (1999) which shows that asset growth has a negative effect on investment risk and research by Yulius Yulianto (2010) states that asset growth has a negative and significant effect on systematic risk (beta). H1: Asset growth has a negative effect on investment risk.

According to Sofyan (2009) Leverage is a ratio that describes the relationship between company debt to capital or assets. This ratio also shows the company's strength to fulfill shortterm and long-term obligations. The higher of company's leverage, so the higher of risk borne by investors. High leverage indicates a low proportion of equity to finance assets. The worst condition for using high leverage is the takeover of the company by creditors. The effect of leverage on investment risk in this study is based on the results of research by Juwita Army (2013) which examines the effect of leverage, liquidity and profitability on systematic risk, the result show the leverage having a positive effect on systematic risk. H2: Leverage has a positive effect on investment risk.

Profitability is a ratio that measures the company's ability to get a profit. This ratio also indicates the company's profit will get from its investment. In other words, the increased profitability of the listed companies will provide a good image regarding the company's future prospects. So that the profit achieved will provide a positive value for the company and will reduce the company's risk. The effect of profitability on investment risk in this study is based on the results of research by Rifat Karakus (2017) which results that profitability has a negative effect on investment risk. H3: Profitability has a negative effect on investment risk.

Company size is a characteristic of a company which is one of the standards for investors to evaluate the risk of the company in terms of the company's characteristics, one of which is seen from the total assets owned. Large companies have high control and competitiveness compared to small companies. In addition, large companies also tend to invest their funds in projects that have a low variance. By investing in a project with a low variance will reduce the risk of the company. The effect of company size on investment risk in this study is based on the results of research by Erni M \& Sylvia N (2015) where company size has a negative and insignificant effect on systematic risk. Hengki (2018) found that company size has a negative effect on investment risk. H4: Firm size has a negative effect on investment risk. 
In this research, the descriptive method is used to describe the Asset Growth, Leverage, Profitability, company size and investment risk variables. The verification method in this study is used to determine the truth of the relationship between asset growth, leverage, profitability and company size on investment risk. The population used is 105 financial reports from 21 coal mining sub-sector companies listed on the Indonesia Stock Exchange (IDX) for the 2014-2018 period. Based on the calculation of the purposive sampling technique above, it can be concluded that will be sampled in this study, that is as many as 95 financial reports from 19 coal mining sub-sector companies listed on the Indonesia Stock Exchange (IDX) during the 2014-2018 period with the following explanation:

Table 2. Criteria for Determination of Research Samples

\begin{tabular}{clc}
\hline No & \multicolumn{1}{c}{ Information } & Amount \\
\hline 1 & $\begin{array}{l}\text { Number of Coal Mining Sub-Sector Companies on the } \\
\text { IDX 2014-2018 }\end{array}$ & 21 \\
2 & $\begin{array}{l}\text { Coal Mining Sub-Sector Companies that do not publish } \\
\text { complete annual report data during the 2014-2018 } \\
\text { period }\end{array}$ & (2) \\
& Number of samples & 19 \\
& Observation data 19 x 5 years & 95 \\
\hline
\end{tabular}

\section{Result and Discussion}

Based on the three panel data model selection test results above, the fixed effect model is better used in this study than the common effect and random effect. The estimation results using a fixed effect model can be formed by the following equation:

$$
\begin{aligned}
\mathrm{Y}_{\mathrm{it}}= & 1,778918+0,064202_{\mathrm{ADRO}}+0,036190_{\mathrm{ARII}}-0,120567_{\mathrm{ATPK}}-0,131356_{\mathrm{BSSR}}+0,285021_{\mathrm{BUMI}}- \\
& 0,307287_{\mathrm{BYAN}}-0,037482_{\mathrm{DEWA}}+0,163029_{\mathrm{DOID}}-0,047876_{\mathrm{GEMS}}+0,049033_{\mathrm{GTBO}}-0,01458_{\mathrm{HRUM}} \\
& -0,030274_{\mathrm{ITMG}}-0,069568_{\mathrm{KKGI}}-0,156525_{\mathrm{MYOH}}-0,05113_{\mathrm{PKPK}}+0,016967_{\mathrm{PTBA}}+0,023248_{\mathrm{PTRO}} \\
& +0,116208_{\mathrm{SMMT}}-0,087311_{\mathrm{TOBA}}-0,089892_{\mathrm{AG}}+0,104201_{\mathrm{DER}}-0,467335_{\mathrm{ROA}}-0,041294_{\mathrm{LN}}+\mathrm{e}
\end{aligned}
$$

Table 3. $\mathrm{t}$ Test Results

\begin{tabular}{crrrr}
\hline Variable & Coefficient & Std. Error & t-Statistic & Prob. \\
\hline C & 1,778918 & 1.663160 & 5.468336 & 0.0321 \\
AG? & $-0,189892$ & 0.162552 & -2.168197 & 0.0019 \\
DER? & 0,104201 & 0.088606 & 3.488224 & 0.0007 \\
ROA? & $-0,467335$ & 0.187920 & -2.486879 & 0.0025 \\
LN? & $-0,041294$ & 0.108410 & -4.180905 & 0.0044 \\
\hline
\end{tabular}

Based on the partial test ( $\mathrm{t}$ test), the results show that asset growth has a negative and significant effect on investment risk. The higher the company's asset growth, the lower of the investment risk that must be borne by investors, on the other hand, the lower of the company's asset growth level, the higher of the investment risk that investors must bear. The higher of the company's asset growth shows that the company has the opportunity to carry out business development, good business development can encourage increased profits. The resulting 
increase in profit is expected to provide benefits for investors. So that the investment risk that will be borne by investors is low. The results of this study are in line with previous research conducted by Elly Indrianto (1999) which resulted that asset growth has a negative effect on investment risk and Yulius Yulianto's research (2010) suggests that Asset Growth has a negative and significant effect on Systematic Risk (Beta).

For the leverage variable, the results show that leverage has a positive and significant effect on investment risk. The higher of the company's leverage, the higher of the investment risk that must be borne by investors, conversely, the lower the level of leverage of a company, the lower the investment risk that investors must bear. A company that uses a debt composition that is too high to finance its obligations indicates that the company has not been able to finance its assets from the company's operations. In addition, companies with high levels of leverage have the risk of taking over the company by creditors when the company is unable to finance its obligations. This is in line with the theory of Utaraja (2005) which states that when a company has a high level of leverage, it will be able to go bankrupt.

The reason is that the higher the use of leverage in a company, the higher the risk of the company being unable to pay debt. The same thing is also stated by Jogiyanto (2005) that the relationship between leverage as measured by DER and stock risk is positively related, where any change in the increase in Der will increase investment risk up to a certain point. The results of this study are in line with previous research conducted by Juwita Army (2013) which examined the effect of leverage, liquidity and profitability on investment risk resulting in leverage having a positive effect on investment risk.

Profitability has a negative and significant effect on investment risk. The higher the profitability of a company, the lower the investment risk that must be borne by investors, conversely, the lower the level of profitability of a company, the higher the investment risk that investors must bear. Companies with high total asset turnover indicate that companies have high effectiveness in managing assets to generate profits. The higher the profit generated by a company is expected to provide benefits for investors, so that the investment risk that will be borne by investors will be lower. The results of this study are in line with previous research conducted by Rifat Karakus (2017) which resulted that profitability had a negative and significant effect on investment risk.

Company size has a negative and significant effect on investment risk, the higher the size of the company, the lower the investment risk that must be borne by investors, conversely, the lower the level of company size of a company, the higher the investment risk that investors must bear. The results of the firm size variable have a negative and significant effect on investment risk in line with the theory of Elton and Gruber (1998) which states that a large company size is considered to have a small investment risk compared to a small company size. The reason is because the larger the size of a company indicates that the company is superior in terms of wealth and good performance, thus reducing investment risk. In addition, a large company is considered to have more access to the capital market, so it has a smaller variant and tends to guarantee going concern and sustainability. So that this is able to contribute to reducing company risk. The results of this study are in line with previous research conducted by Erni M \& Sylvia N (2015) where company size has a negative effect on systematic risk. Hengki (2018) found that company size has a negative and significant effect on investment risk. 


\section{Conclusion}

Based on the results of research and discussion that has been conducted regarding the effect of Asset Growth, Leverage, Profitability and Company Size on Investment Risk in Coal Mining Sub Sector Companies listed on the Indonesia Stock Exchange (IDX) for the 20142018 period, it can be concluded that:

a. Asset growth has a negative and significant effect on investment risk

b. Leverage has a positive and significant effect on investment risk.

c. Profitability has a negative and significant effect on investment risk.

d. Company size has a negative and significant effect on investment risk.

\section{References}

[1] Army, Juwita. 2013. The Effect of Leverage, Liquidity and Profitability on Systematic Risk in Banking Companies Listed on the IDX. Thesis, Faculty of Economics, Department of Accounting, State University of Padang. .(on line). Accessed 08 October 2020.

[2] Jogiyanto. 2005. Decision Efficient Market. Jakarta: PT. Gramedia Main Library.

[3] Jogiyanto. 2013. Portfolio Theory and Investment Analysis. Edition 8. Printing 1. Yogyakarta: BPFE .

[4] Kurniawan Rofiq, A. 2018. The Effect of Accounting Variables on Stock Beta Risk. Journal of Islamic Economics Theory and Applied. Vol. 5 No. 9, pp. 787-799. September 2018. (Aprida Rinaldo, 2018).

[5] Tandelilin, Eduardus. 2001. Investment Analysis and Portfolio Management. Yogyakarta: BPFE.

[6] Yulianto, Yulius. 2010. Analysis of the Influence of Assets Growth, Earning Per Share, Debt To Total Asset, Returns On Investment, and dividend yield on Stock Beta in Banking Companies. Essay. Diponegoro University Semarang. (On line). Accessed October 10, 2020. 